\title{
In situ biological monitoring of radioactivity and metal pollution in terrestrial snails Helix aspersa from a semiarid ecosystem
}

\author{
I. Gaso, N. Segovia and O. Morton ${ }^{1}$ \\ ININ, Ap. Post. 18-1027, 11801 Mexico D.F., Mexico \\ ${ }^{1}$ IGF-UNAM, Ciudad Universitaria, 04510 Mexico D.F., Mexico
}

\begin{abstract}
Soil samples and wild terrestrial snails from a storage centre for radioactive waste site, located in a semi-arid region of Central Mexico, have been analysed as indicators of trace metals pollution and radioactivity. In order to observe, under natural field conditions, the effect of uranium ore tailings and caesium in the soil and snails, some trace element concentrations and specific activities of ${ }^{226} \mathrm{Ra},{ }^{137} \mathrm{Cs}$ and ${ }^{40} \mathrm{~K}$ were measured in the soil, soft tissue and shell. The methodologies include the use of an atomic absorption spectrophotometer, an ICP-MS, an X ray fluorescence spectrometer and a gamma ray spectrometer. The concentration of some toxic elements $(\mathrm{Ba}, \mathrm{Cd}, \mathrm{Cr}, \mathrm{Ni}, \mathrm{Pb}$ and $\mathrm{V})$ in the soft tissue is higher than the toxic level for these elements. Compared with other wild food, snails have relatively high transfer factors for some elements. The importance of this food to the diet, would tend to confirm that its consumption represents an important pathway for the intake of natural and anthropogenic toxic elements and for the delivery of the internal doses to man. The annual effective dose for ${ }^{226} \mathrm{Ra}$ due to ingestion of the snails represents $39 \%$ of the total annual dose from food intake $(0.3 \mathrm{mSv})$.
\end{abstract}

\section{NTRODUCTION}

Garden snails (Helix aspersa Müller) have long been regarded as promising ecological indicators and biomonitoring subjects. The capacity for bioaccumulation of metals, radionuclides and pesticides by the terestrial and freshwater snails, demonstrated both in the field and in the laboratory, makes these invertebrates excellent bioindicators [1-5].

Terrestrial pulmonate gastropods express contamination as a whole through ingestion of polluted food such as live plants, microorganisms, soil, and water but also through cutaneous contact (foot and tegument covered by mucus) and from the polluted air they breathe. The high tolerance of terrestrial snails toward metals in contaminated environments is thought to be due to the high capacity of accumulation and sequestration of heavy metals in their tissues. This resistance is related to the secretion of metallothioneins (metal-binding proteins), to take up excess metals [6]. Snail populations, able to resist high concentrations of pollutants, owing to very efficient systems of storage and detoxification, are, however, subject to sublethal toxic effects when the levels of absorption surpass the rates of the excretory, metabolic, storage and detoxification processes [7].

The impact of natural radioactivity due to uranium and thorium decay series has become an increasingly important environmental question. ${ }^{22} \mathrm{Ra}$, is one of the more radiotoxic radionuclides, being of concern particularly in connection with uranium milling. ${ }^{226} \mathrm{Ra}$, together with ${ }^{40} \mathrm{~K}$ are the main naturally occurring radionuclides, which enter vegetable foods, thereby becoming a source of internal radiation to man and animals. Studies on the histological location of ${ }^{226} \mathrm{Ra}$ in the snails tissues have shown that this radionuclide and other alpha emitters are predominantly located in granular deposits of visceral mass and palps, indicating a discrimination between the distribution of the radionuclide in the corporal mass and in the shell. A preliminary study of ${ }^{226} \mathrm{Ra},{ }^{137} \mathrm{Cs}$ and ${ }^{40} \mathrm{~K}$ content in soils and in land snails, was performed at the confined Storage Centre for Radioactive Waste (SCRW) and at the reference sites, located in a semi-arid region, of Central Mexico $[1,8]$. 
In order to observe, under natural field conditions, the effect of some trace elements, uranium ore tailings and caesium contamination, on the soil and in the wild snail populations living and evolving during more than two decades at the SCRW, the concentration values of trace metal elements and the specific activities of radioactive isotopes were analysed in the soil, in the soft tissue and in the shell of the snails. Reference samples were also collected in regional external sites. Soil-snail transfer factors to different elements have been calculated and the annual effective dose for ${ }^{226} \mathrm{Ra}$ and ${ }^{137} \mathrm{Cs}$ due to the ingestion of the snails were estimated.

\section{EXPERIMENTAL}

The SCRW site $\left(19^{\circ} 47^{\prime} 39^{\prime \prime} \mathrm{N}\right.$; $\left.98^{\circ} 50^{\prime} 04^{\prime \prime} \mathrm{W}\right)$ is located in the middle part of the Neovolcanic Mexican beli at an altitude of $2475 \mathrm{~m}$. No evidence exists of aquifers $30 \mathrm{~km}$ around. The climate is temperate subhumid and the mean annual precipitation is $638.5 \mathrm{~mm}$, mainly during the rainy season, from June to October. The zone has a vegetation characteristic of a semiarid central region of Mexico with species such as: Opuntin megacantha, Opuntia spp., Agave spp., Ferocactus peninsulae, Myrtillocactus geometrizans, Yucca filifera, Larrea tridentata, etc. Local land snails, Helix aspersa, are found mainly when precipitation occurs.

Soil samples of $2.5 \mathrm{~kg}$, corresponding to a total sampling surface of $279 \mathrm{~cm}^{2}$, were picked up fron a topsoil layer $5 \mathrm{~cm}$ thick, sieved to pass a $2 \mathrm{~mm}$ sieve and air-dried. Land snails samples were collected at the SCRW and reference sites $15 \mathrm{~km}$ around. The snails were processed following a previously reported methodology [8].

Snails and soil $(1 \mathrm{~g})$ samples were digested with acids $(10 \mathrm{ml}$ concentrated $\mathrm{HF}$ and $2 \mathrm{ml}$ concentrated $\mathrm{HClO}_{4}$ ) and heated on a hot plate until the appearance of white fumes. The residue was dissolved with $\mathrm{HCl}$ and diluted to a volume of $25 \mathrm{ml}$ with deionised water.

Major elements in the samples were measured with an atomic absorption spectrophotometer Perkin Elmet 2380. Trace elements were determined by inductively coupled plasma-mass spectrometry (ICP-MS) witha VG Elemental-PQ3 equipment. Some samples were crosschecked using an X ray fluorescence spectrometer Ital-Structures, TX-2000. IAEA SOIL 7, SRM-2586 (NIST) and 1573a (NIST) standards were used to validate the analytical procedures.

The samples were also analysed for ${ }^{137} \mathrm{Cs},{ }^{226} \mathrm{Ra}$ and ${ }^{40} \mathrm{~K}$ activity concentration, by low background spectrometry with a HPGe detector, Princeton Gamma Tech., Model N-IGC 29. Appropriate standard mixtures of $\gamma$-ray emitting isotopes were used to calibrate the detector [9]. The geometry used was a $500 \mathrm{~m}$ Marinelli beaker. The measurement time was from $1000 \mathrm{~s}$ to $60000 \mathrm{~s}$. Counting errors for the measurements were usually lower than $10 \%$.

The soil-snails transfer factors (TF and ATF) for soft tissue and the shell were determined for ${ }^{137} \mathrm{Cs},{ }^{20 \mathrm{Ra}}$, ${ }^{40} \mathrm{~K}$ and for other major and trace elements. The specific activity determinations in the soil and in the snals and the concentration levels of stable $\mathrm{Ca}$ were used to calculate the $\mathrm{Ra} / \mathrm{Ca}$ discrimination factor (DF) and the soil-snail concentration factor (CF) for ${ }^{226} \mathrm{Ra}[8]$.

The specific activities for ${ }^{137} \mathrm{Cs}$ and ${ }^{226} \mathrm{Ra}$ in snails, combined with annual local consumption patterns (1) $\mathrm{kg}^{-1}$ (dry wt.)) were used to estimate the annual intake due to this particular seminatural product. The doses have been calculated using, the soil-soft tissue Aggregated Transfer Factor $\left(\mathrm{m}^{2} \mathrm{~kg}^{-1}\right.$ (dry wt.)) and the appropriate dose conversion factors for ${ }^{226} \mathrm{Ra}$ and ${ }^{137} \mathrm{Cs}\left(2 \times 10^{-7} \mathrm{~Sv} \mathrm{~Bq}^{-1} \text { and } 1.3 \times 10^{-8} \mathrm{~Sv} \mathrm{~Bq}^{-1} \text { respectively) }\right)^{8 \cdot}$ 11].

\section{RESULTS AND DISCUSSION}

Soil and land snails content of $\mathrm{Ca}, \mathrm{Na}, \mathrm{Fe}, \mathrm{Mg}$ and $\mathrm{K}$ at the $\mathrm{SCRW}$, together with soil-snail TFs calculations are shown in Table 1. 
Table 1.- Average elemental content in $\mathrm{g} \mathrm{kg}^{-\mathrm{i}}$ (dry wt.), in the soil (SO), soft tissue (ST) and shell (SH) of land snails from SCRW (1994-1997). Soil-land snail transfer factors (TF) for the soft tissue and the shell are also shown.

\begin{tabular}{|c|c|c|c|c|c|}
\hline \multirow{2}{*}{$\begin{array}{c}\text { ELEMENT } \\
\begin{array}{c}\mathrm{g} \mathrm{kg}^{-1} \\
\text { (dry wt.) }\end{array}\end{array}$} & \multirow{2}{*}{$\begin{array}{l}\text { SOIL } \\
(\mathrm{SO}) \\
\mathrm{N}=6\end{array}$} & \multicolumn{4}{|c|}{ LAND SNAILS } \\
\hline & & $\begin{array}{c}\text { SOFT TISSUE } \\
\text { (ST) } \\
N=5\end{array}$ & $\begin{array}{c}\text { SHELL } \\
(\mathrm{SH}) \\
\mathrm{N}=5\end{array}$ & $\begin{array}{c}\mathrm{TF} \\
\text { (ST) }\end{array}$ & $\begin{array}{c}\mathrm{TF} \\
(\mathrm{SH})\end{array}$ \\
\hline $\mathrm{Ca}$ & 32 & 13.35 & 448.56 & 0.42 & $13 . \overline{97}$ \\
\hline$\overline{\mathrm{Na}}$ & 22 & 6.52 & 20.91 & 0.30 & 0.95 \\
\hline $\mathrm{Fe}$ & 31 & 1.87 & 0.4 & 0.06 & 0.01 \\
\hline $\mathrm{Mg}$ & 6.05 & 2.66 & 3.81 & 0.44 & 0.63 \\
\hline $\mathrm{K}$ & 9.57 & 4.85 & 1.32 & 0.51 & 0.14 \\
\hline
\end{tabular}

Natural potassium in the samples was estimated on the basis of the natural ${ }^{40} \mathrm{~K}$ abundance that is equivalent to a relation ${ }^{40} \mathrm{~K}(\mathrm{~Bq}) / \mathrm{K}(\mathrm{g})=30.3 \mathrm{~Bq} \mathrm{~g}^{-1}$ [12]. It is worth mentioning that $\mathrm{K}$ concentrates in the soft tissue, however, the average $\mathrm{Ca}$ in the shell was one order of magnitude higher than in the soft tissue. This result is reflected in the soil-snail TF value for $\mathrm{Ca}$, much higher for the shell than for the soft tissue. Whilst extracting calcium from the environment, the mollusc inevitably takes its chemical analogues ( $\mathrm{Sr}, \mathrm{Ba}$, Ra). Sometimes the presence of one of these elements facilitate the absorption and the uptake of the others; they may exist in the interstitial spaces of the cells as mixed metals/high molecular weight ligand complexes and they may be considered as central atoms of biocatalysts [13].

The average results of trace elements content in the soil and land-snails (soft tissue and shell) at SCRW and the reference are indicated in Table 2, together with the TFs. From these results, higher values were observed in the soil at the SCRW for V, Mn, Co, Ni, Zn, As, Se, Mo, Cd, Sb, Tl, Sr and Ba as compared with the reference.

These elements are related to mining tailings, but also to heavy metal smelting and refining processes. At the site, solid and liquid radioactive waste have been stored in metallic containers during more than two decades: uranium ore tailing piles also stood some time before being buried in specific metallic containers.

Table 2.- Trace elements content ( $\mathrm{mg} \mathrm{kg}^{-1}$ (dry wt.)) and transfer factors (TF) soil-land snails, in the soil (SO), soft tissue (ST) and shell (SH) from the SCRW and the reference site (Ref.), sampled during 1994-1997.

\begin{tabular}{|c|c|c|c|c|c|c|c|c|c|c|c|c|c|}
\hline \multirow{4}{*}{$\begin{array}{l}\text { ELEMENT } \\
\text { mg kg-l } \\
\text { (dry wt.) }\end{array}$} & \multirow{2}{*}{\multicolumn{3}{|c|}{$\begin{array}{l}\text { SOIL } \\
\text { (SO) }\end{array}$}} & \multicolumn{10}{|c|}{ LAND SNAILS } \\
\hline & & & & \multicolumn{5}{|c|}{ SOFT TISSUE (ST) } & \multicolumn{5}{|c|}{ SHELL (SH) } \\
\hline & \multicolumn{2}{|c|}{ SCRW } & \multirow{2}{*}{$\begin{array}{c}\text { Ref. } \\
\text { Av. } \\
\mathrm{N}=2\end{array}$} & \multicolumn{3}{|c|}{ SCRW } & \multicolumn{2}{|c|}{ Ref. } & \multicolumn{3}{|c|}{ SCRW } & \multicolumn{2}{|c|}{ Ref. } \\
\hline & Range & $\begin{array}{c}\text { Av.N } \\
=6\end{array}$ & & Range & $\begin{array}{c}\text { Av. } \\
N=5\end{array}$ & TF & $\begin{array}{l}\text { Av. } \\
\mathrm{N}=2\end{array}$ & $\mathrm{TF}$ & Range & $\begin{array}{c}\text { Av. } \\
\mathrm{N}=5\end{array}$ & TF & $\begin{array}{l}\text { Av. } \\
N=2\end{array}$ & $\overline{\mathrm{TF}}$ \\
\hline $\mathrm{V}$ & $106-430$ & 231 & 80 & $9-20$ & 14 & 0.06 & 11 & 0.14 & $8-34$ & 17 & 0.07 & 8 & 0.10 \\
\hline $\mathrm{Cr}$ & $35-68$ & 57 & 60 & $3.2-5.6$ & 4.4 & 0.08 & 4.8 & 0.08 & $1.1-2.1$ & 1.5 & 0.03 & 1 & 0.02 \\
\hline $\mathrm{Mn}$ & $263-492$ & 392 & 388 & $60-108$ & 77 & 0.20 & 125 & 0.32 & $17-22$ & 18 & 0.05 & 13 & 0.03 \\
\hline $\mathrm{Co}$ & $10-22$ & 15 & 10 & $0.9-1.1$ & 1 & 0.07 & 1.5 & 0.15 & $0 . \overline{8}-5$ & 2.4 & $0 . \overline{16}$ & 1 & 0.10 \\
\hline $\mathrm{Ni}$ & $34-148$ & 71 & 25 & $2-7$ & 6 & 0.08 & 2.5 & 0.10 & $6-55$ & 21 & 0.30 & 5.7 & 0.23 \\
\hline $\mathrm{Cu}$ & $14-195$ & 75 & 78 & $83-101$ & 92 & 1.23 & 104 & 1.33 & $61-273$ & 131 & 1.75 & 162 & 2.08 \\
\hline $\mathrm{Zn}$ & $81-657$ & 369 & 133 & $105-167$ & 115 & 0.31 & 105 & 0.79 & $14-41$ & 23 & $0 . \overline{06}$ & 26 & 0.20 \\
\hline As & $11-108$ & 42 & 8 & $2-5$ & 3.1 & 0.05 & 3.2 & 0.40 & $9-40$ & 22 & 0.38 & 9 & 1.13 \\
\hline $\mathrm{Se}$ & $2-21$ & 9 & 1.4 & $0.4-2$ & 0.9 & 0.10 & 0.5 & 0.36 & $1.0-2.1$ & 1.7 & 0.19 & 1.7 & 1.21 \\
\hline Mo & $6-90$ & 51 & 7 & $5-155$ & 100 & 1.96 & 5.6 & 0.80 & $5-22$ & 11 & 0.22 & 5.7 & 0.81 \\
\hline $\mathrm{Cd}$ & $0.3-\overline{1.7}$ & 0.82 & 0.44 & $3-4.5$ & 4 & 4.88 & 3.4 & 7.73 & $0.2-0.7$ & 0.4 & 0.49 & 0.9 & 2.05 \\
\hline $\mathrm{Sb}$ & $0.5-7$ & 3.2 & 0.56 & $2-4$ & 2 & 0.63 & 1.6 & 2.86 & $0.3-0.5$ & 0.4 & 0.13 & 0.2 & 0.36 \\
\hline $\mathrm{Tl}$ & $4-79$ & 28 & 2 & $0.4-0.9$ & 0.83 & 0.03 & 0.11 & 0.06 & $0.4-2$ & 1.2 & 0.04 & 0.1 & 0.05 \\
\hline $\mathrm{Pb}$ & $18-36$ & 25 & 27 & $4-6$ & 4.8 & 0.19 & 4.1 & 0.15 & $0.6-3$ & 1.6 & 0.06 & 0.5 & 0.02 \\
\hline $\mathrm{Rb}$ & $35-93$ & 57 & 59 & $2-7$ & 4.4 & 0.08 & 2.5 & 0.04 & $0 . \overline{4}-0.6$ & 0.5 & 0.01 & 0.5 & 0.01 \\
\hline $\mathrm{Sr}$ & $241-478$ & 419 & 397 & $157-281$ & 212 & $0.5 \mathrm{I}$ & 140 & 0.35 & $1268-2378$ & 1722 & 4.11 & 1527 & 3.85 \\
\hline $\mathrm{Ba}$ & $401-827$ & 578 & 503 & $1077-1619$ & 1362 & 2.05 & 1087 & 2.16 & $198-590$ & 301 & 0.52 & 195 & 0.39 \\
\hline $\mathrm{Sr} / \mathrm{Ba}$ & & 0.83 & 0.79 & & 0.16 & 0.25 & 0.25 & 0.16 & & 5.7 & 7.9 & 7.9 & 9.8 \\
\hline $\mathrm{Ba} / \mathrm{Sr}$ & & 1.4 & 1.27 & & 6 & 4 & 4 & 6 & & 0.17 & 0.13 & 0.13 & 0.10 \\
\hline
\end{tabular}


At the SCRW, the trace elements having the higher values in soft tissue of the snails were: $\mathrm{V}, \mathrm{Mo}, \mathrm{Ni}, \mathrm{Se}_{\mathrm{e}}$ $\mathrm{Tl}, \mathrm{Rb}, \mathrm{Sr}$ and $\mathrm{Ba}$. At the reference site, TFs in soft tissue higher than 1 were obtained for $\mathrm{Cu}, \mathrm{Cd}, \mathrm{Sb}$ and $\mathrm{Ba}$, while at the SCRW only the TFs for $\mathrm{Cu}, \mathrm{Mo}, \mathrm{Cd}$ and Ba were higher than 1 . In the shell of SCRW tand snails, the higher trace element values as compared with the reference were $\mathrm{V}, \mathrm{Mn}, \mathrm{Co}, \mathrm{Ni}, \mathrm{As}, \mathrm{Mo}, \mathrm{Tl}, \mathrm{Po}$ and Sr. The soil-shell TFs higher than 1 at the reference, were for $\mathrm{Cu}, \mathrm{As}, \mathrm{Se}, \mathrm{Cd}$ and $\mathrm{Sr}$, while at the SCRW only TFs for $\mathrm{Cu}$ and $\mathrm{Sr}$, were higher than 1 .

$\mathrm{Ba}$ for the soft tissue is equivalent to $\mathrm{Sr}$ for the shell. In geochemical processes and probably in the snals, $\mathrm{Ba}$ is usually associated with $\mathrm{K}^{+}$due to their very similar ionic radii. The most abundant mineral form of barium, barite $\left(\mathrm{BaSO}_{4}\right)$, is known to form masses and be associated with limestone $\left(\mathrm{CaCO}_{3}\right)$ and dolomite. $\mathrm{Ba}$ released by weathering is not very mobile because it is easily precipitated as sulphates and carbonetes Varnishes formed at the surface of aridic soils always have an enrichment in Ba. Although barium compounds in high amounts can cause toxic effects such as aberrations in musculoskeletal function, long. term effects of $\mathrm{Ba}$ intake in humans and ecosystems are not well-documented [14].

It is noticeable that $\mathrm{Tl}$ is 14 times higher at the site soil as compared with the reference. Since $\mathrm{Tl}$ is an element generated from the decay of ${ }^{232} \mathrm{Th}$, its enhancement is probably due to the $\mathrm{U}$ tailings. Increased $\mathrm{ll}$ levels in plant tissues are highly toxic to both plants and animals. In the present results $\mathrm{Tl}$ concentrates anomalously both in the shell and in the soft tissue of the snails. The cation $\mathrm{Tl}{ }^{+}$is highly associated with $\mathrm{K}$ and $\mathrm{Rb}$, it tends to bind with sulphide compounds and can interfere with pyruvate in the carbohydrate metabolism [15].

Snails and other organisms can respond in many ways when they encounter with non-essential elemerls such as metals. Possible responses include sequestering the unnecessary metal ion into inaccessible and harmless form within the cell and selecting desired metal ions over unnecessary ones; mechanisms to accomplish this, makes use of ion channels resident in cell membranes or external secretory substances. Zn influences the permeability of membranes, stabilizes cellular components and is believed to stimulate the resistance of many organisms to dry and hot weather. $\mathrm{Zn}-\mathrm{Cu}$ antagonistic interactions have been observedin which the uptake of one element was competitively inhibited by the other. $\mathrm{Cd}$ also binds to sulfhydryl groups and, as $\mathrm{Cd}^{2+}$, can substitute $\mathrm{Zn}^{2+}$ in enzymes [14].

The immobilization of $\mathrm{Zn}$ in soils containing enhanced amounts of certain Ca-saturated minerals such as montmorillonite, has an important impact on the $\mathrm{Zn}$ deficiency of plants and animals. The SCRW polluted with $\mathrm{Zn}$, but the snails that were used to the $\mathrm{Zn}$, accumulated less than those from the unpollitit area. A similar situation was reported in England on sites heavily polluted with $\mathrm{Pb}[16]$. These authors indicate that "sentinel snails, naivve to all prior exposures and hence adaptation, constitute relevant and sensitive indicators". It will be possible to detect the biomarkers (such as metallothioneins, detoxification enzymes, etc.) involved in the biological processes that allow the snails to resist, and sometimes to adapt to the presence of heavy metals [17]. Lead has multiple means of poisoning organisms, including inhibition of such important chemical pathways as heme synthesis and enzymes, including ATPase. Although many studies on metals and snails have consider these metals, there is a strong need for further exploration of their role in snails [16].

The unquestionable tendency of snails to accumulate some metals, anticipates toxicological and environmental consequences in the ingestion dose to the local population. In addition to well-known acule effects, there are subitle chronic and long-term outcomes, such as nephrotoxicity. It should be emphasizid that consumption of the above-mentioned species as a delicacy is a common practice. In few countries, on several occasions, official publications have indeed warned people against the possibility of poisoning caused by heavy metals in wild edible foods from seminatural ecosystems. Cause and effect relationships at not evident for physicians in poisoning cases and probably, some equivocal cases of poisoning may result from repetitive consumption of metal polluted wild foods. The presence of toxic elements such as $\mathrm{Cd}, \mathrm{Cr}$, $\mathrm{Ni}_{1}$ $\mathrm{Pb}, \mathrm{V}$ and $\mathrm{Ba}$ in the dried soft tissue (water content equals $\cong 83 \%$ ) at the SCRW, were higher than the toxic level for these elements $\left(1,1,2,3,10\right.$ and $500 \mathrm{mg} \mathrm{kg}^{-1}$ (dry wt.) respectively) [13].

The ${ }^{226} \mathrm{Ra},{ }^{137} \mathrm{Cs}$ and ${ }^{40} \mathrm{~K}$ specific activity in the soil, snails soft tissue and shell in samples from 1994 to 1997 are shown in Table 3. 
Table 3.- Average ${ }^{226} \mathrm{Ra},{ }^{137} \mathrm{Cs}$ and ${ }^{40} \mathrm{~K}$ (Bq kg (dry wt.)) content in the soil (SO), soft tissue (ST) and shell (SH) of land snails from SCRW and reference (REF.). Soil-land snail transfer factors (TF) for each radionuclide, discrimination factor (DF) and concentration factor (CF) for ${ }^{226} \mathrm{Ra}$ in the soft tissue and the shell are also shown.

\begin{tabular}{|c|c|c|c|c|c|c|c|c|c|c|}
\hline & \multirow{2}{*}{\multicolumn{2}{|c|}{$\begin{array}{l}\text { SOIL } \\
\text { (SO) }\end{array}$}} & \multicolumn{8}{|c|}{ LAND SNAILS } \\
\hline & & & \multicolumn{4}{|c|}{ SOFT TISSUE (ST) } & \multicolumn{4}{|c|}{ SHELL $(\mathrm{SH})$} \\
\hline & $\begin{array}{l}\text { SCRW } \\
(\mathrm{N}=13)\end{array}$ & $\begin{array}{l}\text { REF. } \\
(\mathrm{N}=6)\end{array}$ & $\begin{array}{l}\text { SCRW } \\
(\mathrm{N}=8)\end{array}$ & $\overline{\mathrm{TF}}$ & $\begin{array}{l}\text { REF. } \\
(\mathrm{N}=5)\end{array}$ & $\mathrm{TF}$ & $\begin{array}{l}\text { SCRW } \\
(\mathrm{N}=8)\end{array}$ & TF & $\begin{array}{l}\text { REF. } \\
(\mathrm{N}=5)\end{array}$ & $\overline{T F}$ \\
\hline $226 \mathrm{Ra}$ & 3281 & 36 & 408 & 0.12 & 25 & 0.69 & 129 & 0.04 & 12 & 0.33 \\
\hline$\overline{137 \mathrm{Cs}}$ & 290 & 4 & 31 & 0.11 & 1 & 0.25 & 11 & 0.04 & 0.6 & 0.15 \\
\hline $40_{\mathrm{K}}$ & 290 & 369 & 147 & 0.51 & 209 & 0.57 & 40 & 0.14 & 57 & 0.15 \\
\hline $226 \mathrm{Ra} / \mathrm{Ca}$ & 102 & 1.10 & 30.56 & & 2.480 & & 0.288 & & 0.055 & \\
\hline $\mathrm{DF}_{226 \mathrm{Ra}}$ & & & 0.29 & & 2.246 & & 0.003 & & 0.061 & \\
\hline $\mathrm{CF} 226 \mathrm{Ra}$ & & & & 0.126 & & 0.694 & & 0.041 & & 0.404 \\
\hline
\end{tabular}

The radionuclide content for the snails growing at the site was significantly higher than for the reference. However, the ${ }^{40} \mathrm{~K}$ concentration was similar for both of them. In the soil samples analysed from SCRW and the reference, the average activity of ${ }^{226} \mathrm{Ra}$ and ${ }^{137} \mathrm{Cs}$ were 3281 vs. 36 and 290 vs. $4 \mathrm{~Bq} \mathrm{~kg}{ }^{-1}$ (dry wt.) while for ${ }^{40} \mathrm{~K}$ these values were 290 and $369 \mathrm{~Bq} \mathrm{~kg}^{-1}$ (dry wt.) respectively. The average surficial activities in soil of ${ }^{216} \mathrm{Ra}$ and ${ }^{137} \mathrm{Cs}$ at SCRW were 258340 and $22810 \mathrm{~Bq} \mathrm{~m}{ }^{-2}$ (dry wt.).

Since $\mathrm{Ra}$ and $\mathrm{Ca}$ have similar metabolic behaviour, following a discrimination model, the calculation of the discrimination factor (DF) and concentration factor (CF) were performed with the following relations $[8]$ :

$\mathrm{DF}_{226 \mathrm{Ra}}=\left({ }^{226} \mathrm{Ra} / \mathrm{Ca}\right)_{\mathrm{ST}} /\left({ }^{226} \mathrm{Ra} / \mathrm{Ca}\right)_{\mathrm{so}}$ and $\mathrm{CF}_{226 \mathrm{Ra}}=\mathrm{DF}_{226 \mathrm{Ra}} \times \mathrm{TF}_{\mathrm{Ca}}$. The marked contrast between radium and calcium availability is not surprising in view of the differences in their ionic radii $\left(1.43 \times 10^{-8} \mathrm{~cm}\right.$ and $0.99 \mathrm{x}$ $10^{8} \mathrm{~cm}$ ). The fact that transfer and concentration factors (TFs and CFs) were lower than 1 indicate that the snail-soil concentration factors for ${ }^{226} \mathrm{Ra}$ suffer a strong discrimination, especially for the shell. The values obtained are in agreement with those obtained with the simple linear concentration factor model that only relates the ${ }^{226} \mathrm{Ra}$ activity in the soil and in the snails $[1,8]$.

Knowing the soft tissue and shell activities and the value of the transfer factors for the sampled species, one can estimate the level of radionuclide contamination of the environment. It is possible also to estimate the critical levels of snails activity indicating whether contamination of environment exceed some legal limit or not. ${ }^{90} \mathrm{Sr}$ is considered to be one of the most biologically hazardous radioactive elements for man. Since $\mathrm{Ca}_{\text {and }} \mathrm{Sr}$ are known to be the carrier elements for ${ }^{90} \mathrm{Sr}$, the cycling of ${ }^{90} \mathrm{Sr}$ is related to that of $\mathrm{Ca}$ and $\mathrm{Sr}$. No "Sr values are available, however, the soil-shell TF for $\mathrm{Sr}$, obtained by us $\left(0.05 \mathrm{~m}^{2} \mathrm{~kg}^{-1}\right)$ was lower than previously reported [2] soil-shell TF for ${ }^{90} \mathrm{Sr}\left(0.1 \mathrm{~m}^{2} \mathrm{~kg}^{-1}\right)$ in molluscs from the territories polluted by the Chernobyl outburst. These authors indicated that there are regional differences in strontium uptake rate associated with transfer factors as the free calcium content in the environment and probably with the form of radioactive precipitation.

Considering the actual TF and ATF average values, an estimation of the annual effective dose (E) for ${ }^{20} \mathrm{Ra}$ and ${ }^{137} \mathrm{Cs}$ due to ingestion of the soft tissue of wild edible snails from SCRW and the reference, using the equations previously reported $[8,11]$ gives:

$$
\begin{gathered}
\text { SCRW: } \mathrm{E}_{226 \mathrm{Ra}}=86.8 \mu \mathrm{Sv} \mathrm{y}^{-1} \text { and } \mathrm{E}_{137 \mathrm{Cs}}=4.15 \times 10^{-1} \mu \mathrm{Sv} \mathrm{y^{-1 }} \\
\text { Reference site: } \mathrm{E}_{226 \mathrm{Ra}}=49.98 \mu \mathrm{Sv} \mathrm{y}^{-1} \text { and } \mathrm{E}_{137 \mathrm{Cs}}=0.52 \times 10^{-1} \mu \mathrm{Sv} \mathrm{y}{ }^{-1}
\end{gathered}
$$

The calculated annual dose from ${ }^{226} \mathrm{Ra}$ is higher than the average value of $4 \mu \mathrm{Sv} \mathrm{y}^{-1}$ reported by the local diet in Poland [18]. The annual effective dose for ${ }^{226} \mathrm{Ra}$ due to ingestion of the wild edible snails represents $39 \%$ of the total annual dose from food intake $(0.3 \mathrm{mSv})$ [10]. Considering the high uptake of ${ }^{226} \mathrm{Ra}$ by snails, even small amounts of their ingestion would be sufficient to cause a sharp increase in the equivalent dose to the local population. 
This study provides a basis for estimating intake levels for herbivores and for evaluating transfer coefficients, showing the bioavailability of radium and caesium for molluscs uptake by native species growing at a radioactive waste site. No clear correlation was observed between the concentration levels of a specific trace element in the soil and its concentration in the snail edible part, but compared with other wild food, snails have a relatively high concentration or transfer factors. These factors, together with the importance of this food to the diet of the population, would tend to confirm that its consumption represents an important pathway for the intake of natural and anthropogenic toxic elements and for the delivery of he internal doses to man.

The impact of contamination of the terrestrial environment by radionuclide and metallic trace elementsis difficult to evaluate because of the complexity of soil ecosystems and high soil variability. To predict be environmental impact of chemicals on soil ecosystems in the field, some authors $[4,6]$ propose the use of a laboratory microcosm with land snails in standard conditions, as "sentinels" and metal pollution bioindicators, for the assessment of the bioavailability of metals in their environment. Bioremediation is also emerging as an attractive alternative to high-cost traditional cleaning methods for large areas polluted with low to moderate levels of heavy metals and radionuclides.

\section{Acknowledgements}

The authors acknowledge E. Quintero, E. Hernandez, G. Zarazua, L. Cervantes, G. Valentin, R. Benitez, V. Rojas, F. Montes and I.A. Farráz, for technical assistance.

\section{References}

[1] Gaso I., Cervantes L., Segovia N., Abascal F., Salazar S., Velazquez R. and Mendoza R., Sci. Total Environ. 173 (1995) 41-45.

[2] Frantsevich L., Korniushin A., Pankov I., Ermakov A. and Zakharchuk T., Environ.Pollut. 94 (1996)99. 100.

[3] Lau S., Mohamed M., Tan Chi Yen A. and Su'ut S. Sci. Total Environ. 214 (1998) 113-121.

[4] Gomot de Vaufleury A. and Pihan F., Chemosphere 40 (2000) 275-284.

[5] Gomot de Vaufleury A. and Bispo A., Environ. Sci. Technol. 34 (2000) 1865-1870.

[6] Gomot de Vaufleury A., Ecotoxicol. Environ. Saf. 46 (2000) 41-50.

[7] Graveland J., Van der Wal R., Van Balen H. and Van Noordwijk J., Nature 368 (1994) 446-448.

[8] Gaso I., Segovia N., Cervantes L. and Salazar S. Environmental Radiochemical Analysis (The Royal Society of Chemistry, Edit. G.W.A. Newton, Cambridge, 1999) pp. 50-57.

[9] Quintero E., Lopez H. and Cervantes L. J. Radioanal. Nucl. Chem. Lett. 214 (1996) 309-317.

[10] IAEA, Handbook of Parameter Values for the Prediction of Radionuclide. Transfer in Temperate Environments, Technical Report Series 364 (International Atomic Energy Agency, Vienna, 1994).

[11] Gaso I., Segovia N., Cervantes L., Herrera T. and Perez-Silva E. Radiat. Prot. Dosim. 87 (2000) 213. 216.

[12] Gaso I., Segovia N., Herrera T., Perez-Silva E., Cervantes L., Quintero E., Palacios J. and Acosta E.Sci Total Environ. 223 (1998) 119-129.

[13] Awadalah M., Amrallah H. and Grass F. Environmental Radiochemical Analysis (The Royal Society of Chemistry, Edit. G.W.A. Newton, Cambridge, 1999) pp. 330-342. 
[14] Aruguete D., Aldstadt J. And Mueller G., Sci. Total Environ. 173 (1995) 41-45. [15] Kabata-Pendias A., and Pendias H. Trace elements in soil and plants (CRC Press Inc., Boca Raton,
1985) pp. 315.

[16] Richmond L. and Beeby A., Polish J. Environ. Stud. 1 (1992) 9-13.

[17] Berger B., Dallinger R. and Thomaser A., Environ. Toxicol. Chem. 14 (1995) 781-791.

[18] Pietrzak-Flis Z., Chrzanowski E. and Dembinska S., Sci. Total Environ. 224 (1998) 43-56. 